How women in the UAE enact entrepreneurial identities to build legitimacy

\author{
Helen Thompson-Whiteside* (A) \\ Helen.thomspon-whiteside@port.ac.uk \\ University of Portsmouth, Portsmouth Business School, Portland Street, PO1 3DE \\ Tel: 02393844231 \\ Dr Sarah Turnbull (B) \\ Sarah.turnbull@port.ac.uk \\ University of Portsmouth, Portsmouth Business School, Portland Street, PO1 3DE \\ Tel: 02392844701 \\ Judith Fletcher-Brown (C) \\ Judith.fletcher-brown@port.ac.uk \\ University of Portsmouth, Portsmouth Business School, Portland Street, PO1 3DE \\ Tel: 02393844631
}

Conflict of Interest: Author A declares that she has no conflict of interest. Author B declares that she has no conflict of interest. Author $\mathrm{C}$ declares that she has no conflict of interest *Corresponding author.

\begin{abstract}
This article examines how women enact an entrepreneurial identity as a means to secure legitimacy for their entrepreneurial activity. Using a netnographic analysis of media interviews with women in the United Arab Emirates (UAE), we identify how women construct an entrepreneurial identity. Findings indicate that women highlight micro aspects of their identity, provide both personal and external sources of evidence to substantiate their claims, and adhere to potentially conflicting institutional logics. The findings contribute to knowledge of how entrepreneurship is legitimised and can disrupt institutional arrangements which constrained women. This article provides both a gendered and novel contextual view, adding theoretical depth to contemporary conceptualisations of entrepreneurial legitimacy.
\end{abstract}




\section{How women in the UAE enact entrepreneurial identities to build legitimacy}

The challenge for any entrepreneur in setting up their nascent venture is to overcome the, "liability of newness" (Stinchcombe, 1965:148) and secure legitimacy for themselves and their business activity (Navis and Glynn, 2011; van Werven et al., 2015). Legitimacy is considered to be, 'a generalised perception or assumption that the actions of an entity are desirable, proper, or appropriate within some socially constructed system of norms, beliefs, and definitions' (Suchman, Error! Hyperlink reference not valid. 574). Once secured, it can attract material support and enhance the credibility, social approval, and desirability of a business and its owner (Leitch and Harrison, 2016). While prior research has detailed some of the strategies used by entrepreneurs to legitimise their venture (Alsos and Ljunggren, 2017; Überbacher, Error! Hyperlink reference not valid.), the role of the entrepreneur's identity in securing legitimacy remains underexplored (Leitch and Harrison, 2016; Swail and Marlow, 2018). The process of developing this identity has also received little attention (Leitch and Harrison, 2016) with a tendency within the extant literature to focus on the male, rather than the female, experience of producing an entrepreneurial identity (Hamilton, 2013, 2014; Swail and Marlow, 2018), which has further limited our understanding.

This research seeks to address these gaps and respond to the call for articles in this Special Issue to engage with the rich diversity of female entrepreneurialism. We ask how female entrepreneurs produce an entrepreneurial identity to secure legitimacy. A more detailed examination of the female experience is particularly worthwhile as securing legitimacy may be far from gender neutral (Swail and Marlow, 2018). Instead, entrepreneurship is embedded within institutional biases (Ahl and Marlow, 2012) which constrain ideas of who can claim entrepreneurial legitimacy (Marlow and McAdam, 2015). Entrepreneur, and entrepreneurship are still considered to be male domains (Jennings and Brush, Error! Hyperlink reference not valid.; Henry et al., Error! Hyperlink reference not valid.), to which women might seek belonging (Stead, 2017). Women will often encounter questions of credibility even before they begin (Swail and Marlow, 2018), facing the "dual detriment" of being both new entrants to the field and female (Swail and Marlow, 2018:461), leading to a tendency to view women's entrepreneurship as a lesser form when compared to that of men (Foss et al., 2019; Henry et al., 2016).

To address our research question, we draw on aspects of institutional theory which are related to the legitimatisation of new business ventures (Garud et al., 2014; Rutherford et al., 
2009), and identity theory as it relates to entrepreneurship (Leitch and Harrison, 2016; Swail and Marlow, 2018). We undertake a netnographic study, a methodological approach related to ethnography, in which data collection is achieved through observations of participants in digital communication contexts (Kozinets, 1998). Specifically, we explore how women enact an entrepreneurial identity through media interviews.

Exploring this research question enables us to make three key contributions to enrich the female entrepreneurial literature. Firstly, we provide greater insight to how women construct an entrepreneurial identity as a means to secure legitimacy. We identify how women present a coherent identity by drawing on a number of micro-identities. This identity then derives its legitimacy from sources of evidence taken from differing institutional settings each with their own institutional logics. By highlighting women's engagement with institutional pluralism, we add a new perspective to prevailing debates regarding the relationship between entrepreneurial identity and legitimacy and add to the growing interest in the processes of identity construction (Leitch and Harrison, 2016). Secondly, the extant literature, with some notable exceptions (Swail and Marlow, 2018), has not taken sufficient account of either gender, or gender-in-context, with the underlying assumption that these are neutral. Failing to acknowledge these, risks reproducing only partial understanding of the processes of entrepreneurial legitimacy. By exploring entrepreneurial identity construction within a strongly-gendered institutional setting, we provide a gendered and contextual view which adds theoretical depth to contemporary conceptualisations of entrepreneurial legitimacy. Thirdly, we identify how women negotiate a greater role in the public space within strongly-gendered societies (Bastian et al., 2018) and highlight the role of the media in this process. We therefore usefully add to knowledge of how entrepreneurship may give women increased agency and disrupt existing institutional arrangements.

This article is now structured as follows. We provide a review of relevant literature on legitimacy and entrepreneurial identity to position our article and subsequently provide some detail of the context of the United Arab Emirates (UAE) to inform our study. We outline our research methodology and provide discussion of our findings, highlight limitations and provide suggestions for future research. We conclude with a summary of our contributions and provide managerial implications.

\section{Legitimacy and entrepreneurial identity}


Scholars have highlighted how nascent business ventures must overcome their lack of history or track record (Stinchcombe, 1965; Navis and Glynn, 2011) to establish legitimacy and attract finance. Beyond material support, legitimacy encompasses ideas of credibility, social approval, and desirability (Leitch and Harrison, 2016). What is considered legitimate, within an institutional setting will stem from its accepted customs or prevailing logics (Converse, 1987; Suddaby and Greenwood, 2005). Once established these prescribe appropriate behaviour (Greenwood et al., 2011; Harmon, Green, and Goodnight, 2015) and exert a form of social control (Suddaby and Greenwood, 2005; Thompson-Whiteside et al., 2020). Legitimacy is therefore, a social construct, formed in relation to feedback or affirmation from a wider social group (Suchman, 1995), becoming, in effect, a social judgement (Fisher et al., 2017).

The extant literature portrays the challenge for the entrepreneur seeking legitimacy, as paradoxical. While they may be required to fit in to the culture and norms which prevail within a given context, the logics of entrepreneurialism also require them to stand out (Navis and Glynn, 2011; Swail and Marlow, 2018). They must be different but not appear radical and establish an identity that is both unique and familiar (Lounsbury and Glynn, 2001). In short, they must frame the unknown in a believable way (Middleton, 2013) and, "engineer consent, using powers of persuasion and influence to overcome the scepticism and resistance of guardians of the status quo" (Dees and Starr, 1992: 96). Prior research has highlighted some of the strategies used by entrepreneurs to secure and manage this legitimacy. These include providing evidence of sales or finance (Orser et al., 2020; Tornikoski and Newbert, 2007), attaining certification (Rao, 2008), impression management (Nagy et al., 2016; Rutherford et al., 2009), storytelling (Garud et al., 2014; Lounsbury and Glynn, 2001), or building social capital by highlighting associations with key figures or networks (Alsos and Ljunggren, 2017). However, the identity of the entrepreneurial actor can also act as proxy for the nascent venture (Fisher et al., 2017; Nelson et al., 2016; Überbacher, Error! Hyperlink reference not valid.), with the construction of an appropriate identity seen by some to be central to the process of securing legitimacy (Fisher et al., 2017; Greene et al., 2013; Swail and Marlow, 2018). Yet, the literature has had less to say about how identity is produced (Gioia et al., 2013a; Leitch and Harrison, 2016), with the male experience still dominant (Hamilton, 2014; Swail and Marlow, 2018). We contribute to this debate by focusing on how the identities of entrepreneurs are enacted, in order to secure legitimacy for women's business activity. 
Entrepreneurial identity is defined by Navis and Glynn $(2011 ; 480)$ as, "the constellation of claims around the founders, organisation, and market opportunity of an entrepreneurial entity that gives meaning to questions of "who we are" and "what we do"'”. Such claims might be made by individuals but identity is produced in negotiation with others (Leitch and Harrison, 2016; Stets and Burke, 2000), embedded in social conditions (Granovetter, 2000; Middleton, 2013), and created in dialogue between the internal self and the wider discourses encountered within the social context (Sveningsson and Alvesson, 2003; Lewis, 2015). In effect, identity is developed and redeveloped over time, through social and relational processes (DeRue and Ashford, 2010; Hsu and Hannan, 2005), with the favourable judgements of others serving to legitimise this identity (De Clerq and Voronov, 2009).

However, an entrepreneurial identity must be reconciled with existing social and role identities (Fauchart and Gruber, 2011; Navis and Glynn, 2011), including wife or mother. Women may seek to overcome any possible tensions between the identities ascribed to them by society and gender, and the desired identity of entrepreneur. Stets and Burke (2000) overcome possible antagonism between these by allowing for the concepts of group, role and person to be considered together. Rather than view self or social identity separately, Down (2006) also sees them as different aspects of one holistic identity, while Newbury et al. (2018) draw on the work of Shepherd and Haynie (2009) to argue for the existence of microidentities which taken together comprise one "super-ordinate" identity. We similarly propose that individuals might draw on various micro-identities, emphasising different aspects of their persona to construct a legitimate entrepreneurial identity in response to their social conditions. Individuals might choose to highlight certain aspects of their identity whilst downplaying others, regulating the information they make available through impression management, (Nagy et al., 2012; Thompson-Whiteside et al., 2018, 2020; Uberbacher, 2014). In this way, as Anderson and Warren (2011:605) argue, "an entrepreneurial identity is sufficiently malleable to allow practising entrepreneurs to employ it to build their own individualised identity", yet the construction of this identity remains underexplored.

Prior literature also recognises the role of media attention in helping to secure legitimacy (Lamin and Zaheer, 2012; Vaara and Monin, 2010). In particular, scholars have highlighted the role of the media in reflecting both, what is already considered legitimate and in influencing what might be considered legitimate in the future (Deephouse, 1996; McCombs and Shaw, 1972; Pollock and Rindova, 2003), but few studies have explored its role in legitimising entrepreneurial identity. 


\section{Summary}

Although there is recognition that the identity of "entrepreneur" is embedded in social conditions (Granovetter, 2000; Middleton, 2013), with legitimacy considered a social judgement (Fisher et al., 2017), the social formation of the entrepreneurial self, is still an under-developed area of research (Leitch and Harrison, 2016). Whilst we recognise the value of the extant literature which explores legitimacy for entrepreneurs, we argue that many of these studies presume gender and context to be neutral, with the influence of both insufficiently recognised. Instead, we argue that these factors are important to a richer understanding of female entrepreneurship. We theorise that women will engage in specific tactics to overcome any tensions or gaps between the identities ascribed to them by society and gender, and the identity of entrepreneur which they seek to produce (Swail and Marlow, 2018). Therefore, understanding how female entrepreneurs negotiate institutional arrangements to construct an entrepreneurial identity as a means to secure legitimacy, will develop our theoretical understanding of how female entrepreneurs become legitimate entrepreneurial actors. We propose that a legitimate female entrepreneurial identity will emerge from the convergence of three theoretical concepts as shown in Figure 1. 


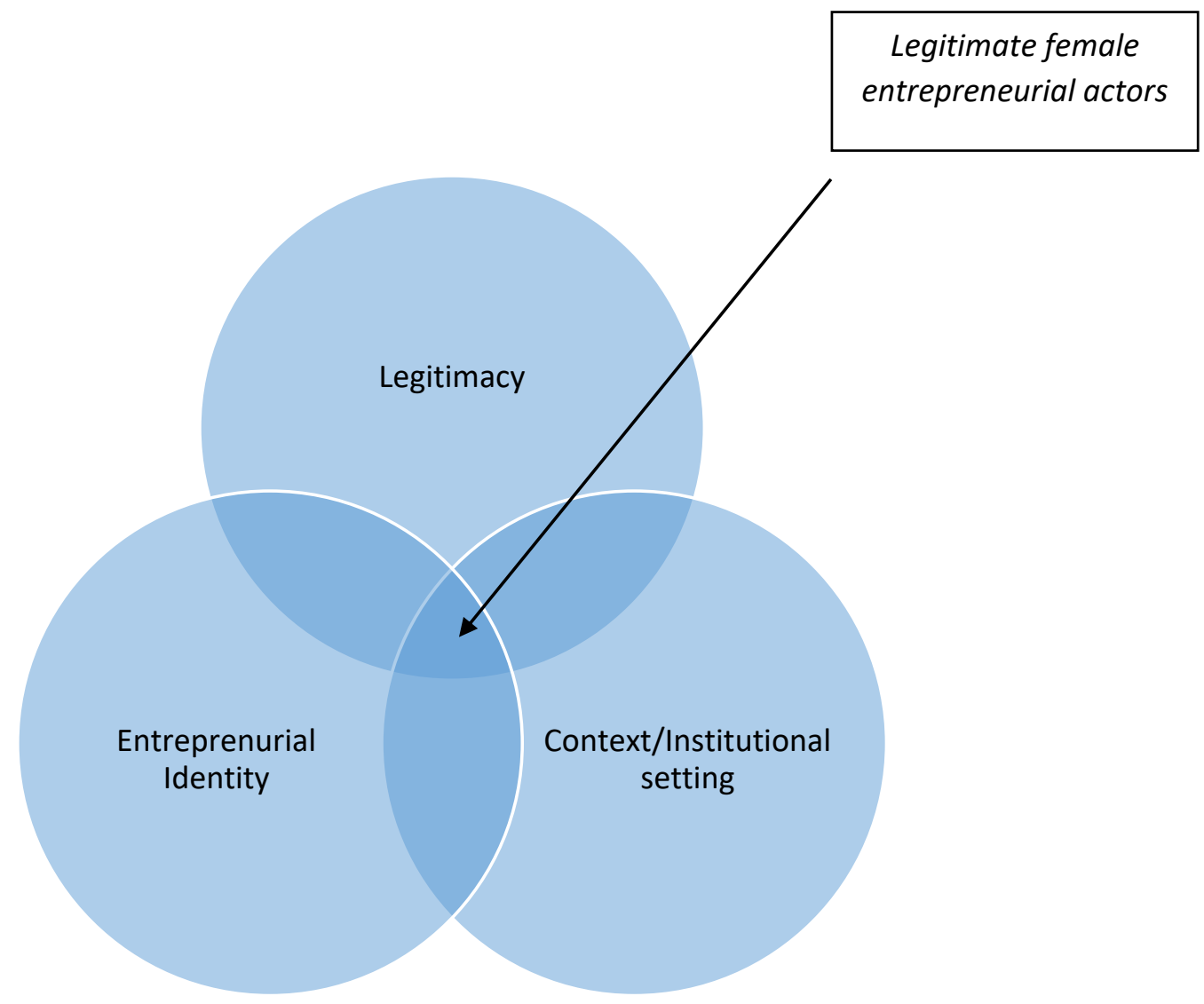

Figure 1: The theoretical concepts which give rise to the emergence of a legitimate female entrepreneurial identity.

\section{Context}

To explore our research question, we undertake exploratory research within the institutional setting of the UAE. This allows us to develop our theoretical understanding of the role of cultural forces in shaping the entrepreneurial process (Welter, 2011; Welter et al, 2017). It also responds to the call for greater emphasis on context in entrepreneurial research (Shirokova et al., 2018; Stead, 2017; Welter, 2011), particularly of the MENA region, where understanding of how women negotiate a greater public role remains underexplored (Bastian et al., 2018; Kiss et al., 2012; Tlaiss, 2015). Within the UAE, the National Agenda 2021 sets ambitious goals around entrepreneurship, stating an intention for, "the UAE to be among the best in the world in entrepreneurship" (Vision 2021, 2020:1). With women considered less likely to engage in entrepreneurial activity (Erogul et al., 2019; El-Sokari et al., 2020), initiatives to encourage female entrepreneurship in the country have now been introduced. A businesswomen's council has been established across the seven Emirates that constitute the 
UAE, and new funding sources set up to support women's business ventures (Goby and Erogul, 2011). As a result, women's engagement in entrepreneurial activity has increased in recent years (Goby and Erogul, 2011; Itani et al., 2011; Tlaiss, 2015), with the levels of women participating in entrepreneurial activities climbing from 0.2 to $1.4 \%$ between 2006 and 2016 (El-Sokari et al., 2020).

However, in considering how female entrepreneurs construct and enact identity within the institutional setting of the Arab Middle East, a paradox soon becomes clear. Women clearly face pluralistic institutional expectations. Despite government support for the growing number of female entrepreneurs in the Middle East (El-Sokari et al., 2020; Erogul et al., 2019) and increased freedom of movement (BBC, 2019; Kirdar, 2010), persistent institutional logics mean women still face many informal restrictions in the UAE which limit their entrepreneurial activity (Erogul et al., 2019; Hattab, 2012; Tlaiss, 2013, 2015). Despite the legal freedom to travel, many Emirati women are not free to travel abroad for work unless accompanied by their husband or a male family member (Kirdar, 2010) with patriarchal values strongly influencing female career choices (Goby and Erogul, 2011; Williams et al., 2013). Women are still ascribed roles as mother and homemaker (Goby and Erogul, 2011; Tlaiss, 2013) making female employment outside the home still unusual (Itani et al., 2011). Consequently, women's independent economic activity challenges social expectations, and can invoke unfavourable attitudes towards them (Zeidan and Bahrami, 2011). Consequently, women's career decisions will often be the result of careful negotiations with family (HoweWalsh et al., 2020). Fathers in particular appear to have a strong influence on female career choice and Emirati women are often required to enter into a 'patriarchal bargain' to allow them to enter the workplace (Williams et al., 2013). They are also encouraged to work in organisations, usually within the public sector, that are seen to be respectable with a good reputation (Howe-Walsh et al., 2020). We therefore seek to understand how women construct an entrepreneurial identity to secure legitimacy, in a context where their professional identities are constrained by societal norms.

\section{Methodology}

Using an exploratory approach, the purpose of this study is to examine how women produce an entrepreneurial identity to secure legitimacy in the UAE. Women in the Middle East are noted to be particularly hard to access, often requiring access to gatekeepers (Howe-Walsh et al., 2020). To overcome this potential barrier, the researchers chose to use netnographic 
research methods (Fletcher-Brown et al., 2020; Kozinets, 1998) to gain a rich understanding of how women in the UAE are constructing and enacting an entrepreneurial identity. Online media interviews with female entrepreneurs in the UAE were examined as interview dialogues are seen to provide a rich understanding of a particular community (Hamman, 2007; Laverty, 2003). Interviews were analysed using a three-tiered coding system as suggested by Gioia et al. (2013b) to enable key concepts to be identified within the data. These concepts were further analysed to identify patterns or themes within the data and then a set of aggregated dimensions. These aggregated dimensions allowed the researchers to identify and describe commonalities which were shared by the women (Orser et al., 2019). Exploring the commonalities within the data in this qualitative manner allowed for new conceptualisations of female entrepreneurship to be identified.

\section{Data and sample}

We purposely selected online interviews with female entrepreneurs operating in the UAE from the Middle East's leading weekly business title published during 2018-2020. The journal provides a multi-platform news source and focuses on the English and Arabic speaking communities. Previous research on female entrepreneurship has established valuable contributions to theory using a purposive sample of participants (Orser et al., 2011). This approach allowed us to focus on participants who self-identified as female entrepreneurs active in the UAE (See Table 1). The transcripts of these interviews provided rich textual data with data saturation reached after analysis of 24 interviews (Guest et al., 2006).

Table 1. Characteristics of participants

\begin{tabular}{|c|c|c|c|c|}
\hline $\begin{array}{l}\text { Participant } \\
\text { identification }\end{array}$ & Occupation & Expertise & Education & Location \\
\hline 1 & $\begin{array}{l}\text { Entrepreneur/ } \\
\text { practitioner }\end{array}$ & $\begin{array}{l}\text { Neurolinguistic } \\
\text { Programming coach }\end{array}$ & $\begin{array}{l}\text { Certified } \\
\text { counsellor }\end{array}$ & Dubai \\
\hline 2 & Entrepreneur & PR/Fashion & $\begin{array}{l}\text { Digital } \\
\text { Marketer }\end{array}$ & Middle East \\
\hline 3 & Entrepreneur & $\begin{array}{l}\text { Online discount shopping } \\
\text { site }\end{array}$ & Finance & UAE \\
\hline 4 & $\begin{array}{l}\text { Entrepreneur/social } \\
\text { enterprise }\end{array}$ & $\begin{array}{l}\text { Creating cultural } \\
\text { experiences for those in } \\
\text { isolation }\end{array}$ & $\begin{array}{l}\text { MA degree, } \\
\text { UK. }\end{array}$ & UAE \\
\hline 5 & Entrepreneur & $\begin{array}{l}\text { Dream wedding dresses } \\
\text { hire }\end{array}$ & Unknown & UAE \\
\hline 6 & $\begin{array}{l}\text { E-commerce } \\
\text { Entrepreneur }\end{array}$ & Activities for children & $\begin{array}{l}\text { BA, UK. } \\
\text { Finance }\end{array}$ & UAE \\
\hline 7 & $\begin{array}{l}\text { E-commerce brand } \\
\text { Entrepreneur }\end{array}$ & On line influencer & Unknown & UAE and USA \\
\hline
\end{tabular}




\begin{tabular}{|c|c|c|c|c|}
\hline 8 & CEO and Co-Founder & $\begin{array}{l}\text { Luxury Hair and beauty } \\
\text { salons }\end{array}$ & Unknown & Dubai \\
\hline 9 & $\mathrm{CEO}$ and Co-Founder & Learning design initiatives & $\begin{array}{l}\text { MA degree, } \\
\text { USA, }\end{array}$ & UAE \\
\hline 10 & Entrepreneur/Founder & $\begin{array}{l}\text { Personal styling, luxury occa: } \\
\text { wear }\end{array}$ & Unknown & Dubai \\
\hline 11 & Entrepreneur & $\begin{array}{l}\text { Fashion, technology and } \\
\text { marketing }\end{array}$ & Unknown & UAE \\
\hline 12 & CEO / consultant & $\begin{array}{l}\text { Corporate luxury brand } \\
\text { strategies }\end{array}$ & Unknown & Middle East \\
\hline 13 & $\begin{array}{l}\text { Human resources } \\
\text { consultant }\end{array}$ & Family manufacturing & Unknown & UAE \\
\hline 14 & Entrepreneur & $\begin{array}{l}\text { Online discount shopping } \\
\text { site }\end{array}$ & Finance & Middle East \\
\hline \multirow[t]{2}{*}{15} & Entrepreneur/ inventor & Robotic technology & Unknown & UAE \\
\hline & Founder/entrepreneur & $\begin{array}{l}\text { Online marketplace, baby } \\
\text { and children's products }\end{array}$ & Unknown & Middle East \\
\hline 16 & $\begin{array}{l}\text { Entrepreneur and Co- } \\
\text { Founder }\end{array}$ & Children's craft products & MBA, USA. & \\
\hline 17 & $\begin{array}{l}\text { Entrepreneur and Co- } \\
\text { Founder }\end{array}$ & Children's craft products & $\begin{array}{l}\text { MBA, UK. } \\
\text { MA, France. }\end{array}$ & \\
\hline 18 & $\begin{array}{l}\text { Entrepreneur/event } \\
\text { manager }\end{array}$ & $\begin{array}{l}\text { Change maker for female } \\
\text { entrepreneurs }\end{array}$ & Unknown & Middle East \\
\hline 19 & Founder and CEO & $\begin{array}{l}\text { Online provider stock } \\
\text { images and digital content }\end{array}$ & IT & $\begin{array}{l}\text { Middle } \\
\text { East/USA }\end{array}$ \\
\hline 20 & Founder and CEO & Online Video recipe site & Unknown & Middle East \\
\hline 21 & Founder and joint CEO & $\begin{array}{l}\text { Exclusive Fashion } \\
\text { Boutique, }\end{array}$ & Unknown & Dubai \\
\hline 22 & Founder and CEO & Price comparison website & MBA, UK & $\begin{array}{l}\text { Middle } \\
\text { East/India }\end{array}$ \\
\hline 23 & Film Director & Free-lance film director & Unknown & UAE \\
\hline 24 & Founder and CEO & $\begin{array}{l}\text { Chocolate manufacturer } \\
\text { and Luxury restaurants }\end{array}$ & Finance & $\begin{array}{l}\text { Bahrain } \\
\text { Middle East }\end{array}$ \\
\hline
\end{tabular}

\section{Data analysis}

The data was analysed using the Gioia method (Gioia et al, 2013b). This interpretive approach requires the researcher to track back and forth from the data to the literature to allow for 'sensemaking' of the phenomenon (Gioia and Chittipeddi, 1991). Following Gioia et al (2013b), a three stage process was used to examine the data which identifies: 1st- order concepts, 2nd-order themes; and $3^{\text {rd }}$ - order aggregate dimensions. Rather than be restricted by a priori constructs, the researchers used this style of thematic analysis to explore how female entrepreneurs construct an entrepreneurial identity as a means to secure legitimacy.

To begin with, the researchers read and re-read the interviews, immersing themselves in the data and making a list of $1^{\text {st }}$ order concepts. This allowed the key terms and codes to emerge from the female entrepreneurs' own words, without any attempt to organise concepts into broader categories. During the next stage, all the researchers met to discuss similarities 
and differences between the 1st-order concepts. Any disagreements were discussed between members of the research team until agreement was reached. In line with Gioia et al (2013b), we concentrated on reviewing new concepts that have not been explored previously in the literature, enabling us to highlight new theoretical viewpoints about identity work being undertaken by these entrepreneurs. We identified forty-four $1^{\text {st }}$-order concepts from the data which highlighted the sources of evidence the female entrepreneurs draw upon when constructing their identity in the media. At this stage it was very clear that female entrepreneurs drew upon both personal and external sources of legitimacy. Therefore, the researchers separated the sources into personal and external to allow for further data reduction.

Following this separation of sources, the data relating to both personal and external sources was reduced again into $2^{\text {nd }}$-order themes. These themes represented a higher order of data reduction and resulted in the creation of nine themes for personal sources and six themes for external sources. Each of these themes were discussed among the research team and following agreement on each theme, the data was summarised into seven final 3rd- order aggregate dimensions. For Personal Sources, there were three final aggregate dimensions; Personal narratives, Personal accomplishments and Personal characteristics. For External Sources, there were four aggregate dimensions; External endorsement, External funding, External support and External impact. The results of the analysis were presented in two tables (Table 2 and Table 3) and were discussed with all members of the research team to confirm agreement of the final aggregated dimensions. The results of the data analysis are discussed in the Findings section presented below.

\section{Findings}

The data was examined to explore how female entrepreneurs are constructing and enacting entrepreneurial identity. In particular, we questioned what sources the women draw upon in their interviews to construct their identity and seek legitimacy. Tables 2 and 3 present an inventory of responses. While some of the sources are consistent with the resources reported in the literature, such as stories and personal characteristics, we are able to identify how a combination of specific factors are highlighted by the female entrepreneurs in their efforts to construct an entrepreneurial identity. 


\section{Personal Narratives}

Stories were commonly used within the interviews. Some of the women used the interview to share how they had overcome personal adversity in their lives. These personal narratives often contained a 'crucible experience' which was used to provide a rationale for starting the entrepreneurial adventure. However, they also provide a compelling 'backstory' to the entrepreneur, and give insight into their character.

"I read about the famous path in Spain, Camino de Santiago, in a Paulo Coelho book, and one day I decided to hike it. I did the hike for seven days and then did another in Austria - by myself - that was very hard, I hiked in the forest alone for the first time, and then I did Switzerland too. It was very rich and I thought, why don't I bring women from our region to do something like this? So I started. I just wanted to try something new, because we don't have hiking [in our culture]. We're a desert country”.

Women often began interviews with personal stories about the hardship they had faced in their early lives and shared experiences of the stigmatisation and isolation they had encountered. Drawing on poverty and exclusion within the narratives helps to secure the role of heroine for the entrepreneur and provided a justification for the entrepreneurial activity, both emotionally and financially.

"I was born in the Gulf to a large family and parents of simple backgrounds and who, because of the war, were forced to move back to their home in the Levant emptyhanded. My family and I tried hard to immerse ourselves into our new lives, the system, and engage with the community, but to little avail, as we were not welcomed. Our different accent and mannerisms and the way we conducted ourselves stood between us and the community. It was an unpleasant experience for all of us, and for a seven-year-old (me) it was difficult to understand the new dynamics and get a grasp over my family busily trying to secure food and manage education expenses.... I spent 15 years in cultural isolation..."

Cultural exclusion and challenges within society were evoked within the narratives, with women sharing how their entrepreneurial venture had enabled their personal development, as one woman says, "I learnt how to face your fears and I overcame social restrictions". As part of their own personal story, women shared how they had overcome issues of confidence associated with being a female entrepreneur, "I had to overcome many silent voices within 
me, telling me she can't do it and shouldn't go through with it', highlighting their own selfdoubt about their prescribed role within society.

Using a personal narrative to build an identity not only for themselves but also for their business, was acknowledged by some women. In the case of a wedding dress retailer, the entrepreneur referred to the inclusion of the story on their website, "I go into detail of my wedding story on the site and I think these small personal touches give our customers a trust in us".

\section{Personal Accomplishments}

The female entrepreneurs also used the interviews to showcase their accomplishments in the arts, education and business. Achievements outside their current entrepreneurial role were shared, providing a richer insight into the women's talents, "I'm an artist so I used to paint". They also highlighted their educational achievements within the interview, particularly Masters Degrees or MBAs. Of particular interest, was the emphasis most women placed on the international nature of their qualifications. They also shared details of credentials and work experience, often highlighting the prestige of the companies they had worked for prior to starting their venture, "At Deloitte I came across a number of businesses in the ecommerce space", and

"I did a Bachelor's in Computer and then a Masters in Business, followed by a profession in the consultancy industry. I then became a regional senior manager with one of the international consultancy companies, before I resigned and started [name of business]."

Women chose to showcase their experiences of international travel for both leisure and business purposes. This featured heavily within the interviews with some of the women highlighting how many different languages they spoke. Women also highlighted their technical and digital skills. While some of the businesses were technical in nature, women more generally wanted to showcase their technical ability and referred frequently to their technical and analytical competence within the interviews. Digital marketing skills were just one type of competency communicated in the interviews.

"We additionally promote these deals through various online marketing techniqueslike Search Engine Optimization (SEO), email marketing, social media and other streams to drive sales for our partners." 


\section{Personal Characteristics}

There were a number of personal characteristics which female entrepreneurs appeared keen to reveal in the interviews. It was clear that most women wanted to give the impression that they were hard-working, "persistence is key for us" and passionate about their business. The passion for their business was demonstrated in the interviews with declarations such as, "I am doing what I love". The combination of hard-work and passion for what they did was a central theme throughout many of the interviews.

"As with all things, a little luck and a lot of hard work went a long way for me. I hit a few roadblocks with my job and I had always felt I was yet to find my calling. In the process of reflecting on my core interests and passions."

A desire to communicate their dedication to the business, as well as revealing involvement in other business ventures was clearly discerned in the interviews. Women depict themselves as hard-working and passionate business owners. As one women highlights, this is clearly linked to a desire to earn respect,

"If you are passionate and are prepared to work incredibly hard, then that earns the respect of everyone you interact with; be it a potential business investor or your colleagues and peers."

The interviews were also used to communicate their vision and in many cases, a desire to achieve international business success, "we aim to create a global presence for the site in the next 5 years, with the attention of working women", with another woman sharing, "we are also in discussions with community integration departments in Germany and Canada". Many of the women not only provided a vision of their business venture, but also used the interview to showcase their conviction that the business would be successful.

Women illustrated their self-sufficiency, with some sharing how they financed their business through bootstrapping. This also appears to be consistent with their desire to gain respect as a legitimate female entrepreneur. While others had initially gained funding for the venture from family or friends, they were clear that the funds had been secured on merit. 
"I approached my father to be an investor. He went through my plan and my feasibility study, which impressed him enough to decide to invest. But all the other branches and businesses that came afterwards were self-funded."

In summary, women present themselves as independent business women who had achieved success in their own right. Women showed they had a vision of the business and the conviction that they would be able to realise their goals through hard-work.

\section{External Endorsement}

Analysis of the interviews also showed that the women chose to highlight the endorsement they had received from external organisations and bodies. This included both national and international accolades that had been awarded to the entrepreneurs.

"We won the first prize at the Pitch Rising Pitch finale hosted by Mompreneurs

Worldwide in December 2018 and reached the top three at the pitch competition hosted by Step Conference 2019, which had over 2,000 startups apply from the region."

Endorsement from celebrities was highlighted, illustrating the entrepreneurs' associations with both industry and global celebrities.

"We were also the first to introduce master classes to the region, starting with Makeup by Mario in 2014, followed by the Master Class of Hair and Makeup with Khloe Kardashian, and Fouz Al Fahed as models for hair and makeup. The celebrity hairstylist and make-up artists for this class were again well-known celebrities. We also organised a master class with Olivia Culpo and this year we had the biggest master class in the region: Makeup by Mario with Kim Kardashian."

\section{External Funding}

Although many were proud to have self-financed their business ventures, some women also shared how they had received funding from national and international investors, "we've been incredibly fortunate to raise substantial sums from both here and Europe”. Funding was openly discussed by the women in the interviews as a means to communicate wider endorsement of both them, and their business ventures. 


\section{External Support}

The women highlighted the support they had received from their families and friends. In particular, many women mentioned the support given by male members of their family, such as fathers or husbands, highlighting the significance of male endorsement in this highly patriarchal society. Both governmental support and the support of friends was also referred to within the interviews providing further evidence of how important it is for these women to be legitimised by the nation and their community.

"We have now been selected by Dubai Chamber of Commerce as one of the three startups that will be showcased under their education pillar to schools and universities in the city."

\section{External Impact}

Additionally, the interviews revealed the apparent importance for these women to be seen as having an impact on the wider society. This external impact was evidenced in a number of ways. In some cases, the women communicated how they wanted to be seen as role models for other entrepreneurs.

"I'm going on the show determined to make a positive impact and to encourage other young, aspiring entrepreneurs to create something meaningful that positively impacts the future of humanity."

The women also shared their desire to help their industry sector within the country by providing training for less experienced employees, "I opened [name of academy] specifically to train not only our employees but also employees from other salons". The interviews positioned the women as aspiring to impact society more broadly, "our objective is to replace cultural misconceptions with empathy and understanding". By highlighting their goals to address cultural stereotypes and change expectations of women in business, these female entrepreneurs sought to create an impression of their businesses having a higher purpose and suggested they were driven by more than just financial rewards.

\section{Discussion}

Our findings highlight the dedicated identity work female entrepreneurs in the UAE undertake to secure and manage legitimacy for themselves and their business ventures. Although this identity makes a variety of claims, it appears to answer more of the questions about "who" the entrepreneur is, rather than answer questions about "what" they do (Navis 
and Glynn, 2011). Women build an entrepreneurial identity from a range of micro-identities including artist, student, business woman, daughter, mentor, visionary and public figure. drawing on differing parts, or "micro" aspects of women's identities. We therefore find evidence of how a coherent identity can be constructed which integrates person, role and social identities (Newbury et al., 2018; Shepherd and Haynie, 2009; Stets and Burke, 2000), Women select personal narratives and characteristics and regulate the information they share in order to manage the impression they make (Nagy et al., 2012; Rutherford, 2009) as they seek legitimacy. We therefore find further evidence of entrepreneurial identity acting as a proxy for the nascent venture (Fisher et al., 2016; Nelson et al., 2016; Überbacher, Error! Hyperlink reference not valid.). However, in a strongly-patriarchal setting, questions of "who" women are, and can be, must be negotiated with a range of powerful actors.

We therefore highlight the process by which women produce this identity to appear legitimate to an external audience. We find that women claim legitimacy for their entrepreneurial identity by drawing on those personal and external sources of evidence which are valued within differing institutional settings. By sharing details of their finances, their connections and the recognition they have received, they appear to draw on the institutional logics of their immediate setting to demonstrate support from both government and family and claim socio-political legitimation (Aldrich and Fiol, 1994). We therefore find evidence of the social formation of an entrepreneurial identity which has been underexplored (Leitch and Harrison, 2016; Middleton, 2013). However, we also find that women seeking legitimacy as an entrepreneur, draw on logics from other institutional settings. They highlight their overseas work experience, their engagement with the private sector, their higher education and the international scope of their business. Such evidence appears to indicate their adherence to what might be described as Western ideals, such as personal development, global travel, international business experience and education.

An entrepreneurial identity constructed from such institutional pluralism, enables women and their business ventures to meet the threshold criteria for legitimacy, including the need to both fit in and stand out, to be both familiar and different (De Clerq and Voronov, 2009; Lounsbury and Glynn, 2001; Middleton, 2013; Navis and Glynn, 2011; Swail and Marlow, 2018). This also provides evidence of how women are negotiating a bigger role in the public space than that which is usually afforded in the immediate institutional setting (Bastian et al., 2018). Female entrepreneurs appear to be deliberately regulating information to provide evidence that are not constrained by the gender roles usually ascribed to women in 
this patriarchal setting. They also explicitly claim to be having an impact on this public space and share their desire to inspire other women to similarly occupy and expand this space. We therefore offer Figure 2 as a more nuanced revision of our initial conceptual model. (See Figure 2 below as a conceptualisation of how legitimate female entrepreneurial identities are enacted).

Our findings also suggest an entrepreneurial identity is being produced by women through media dialogue and therefore highlight the role of the media in conferring legitimacy on this identity. While prior literature has brought this to our attention (Pollock and Rindova, 2003), we highlight its role in legitimating female claims on an entrepreneurial identity. Such media dialogue also reflects the iterative process of identity construction and supports previous notions that identities are living entities (Goia et al., 2013a).

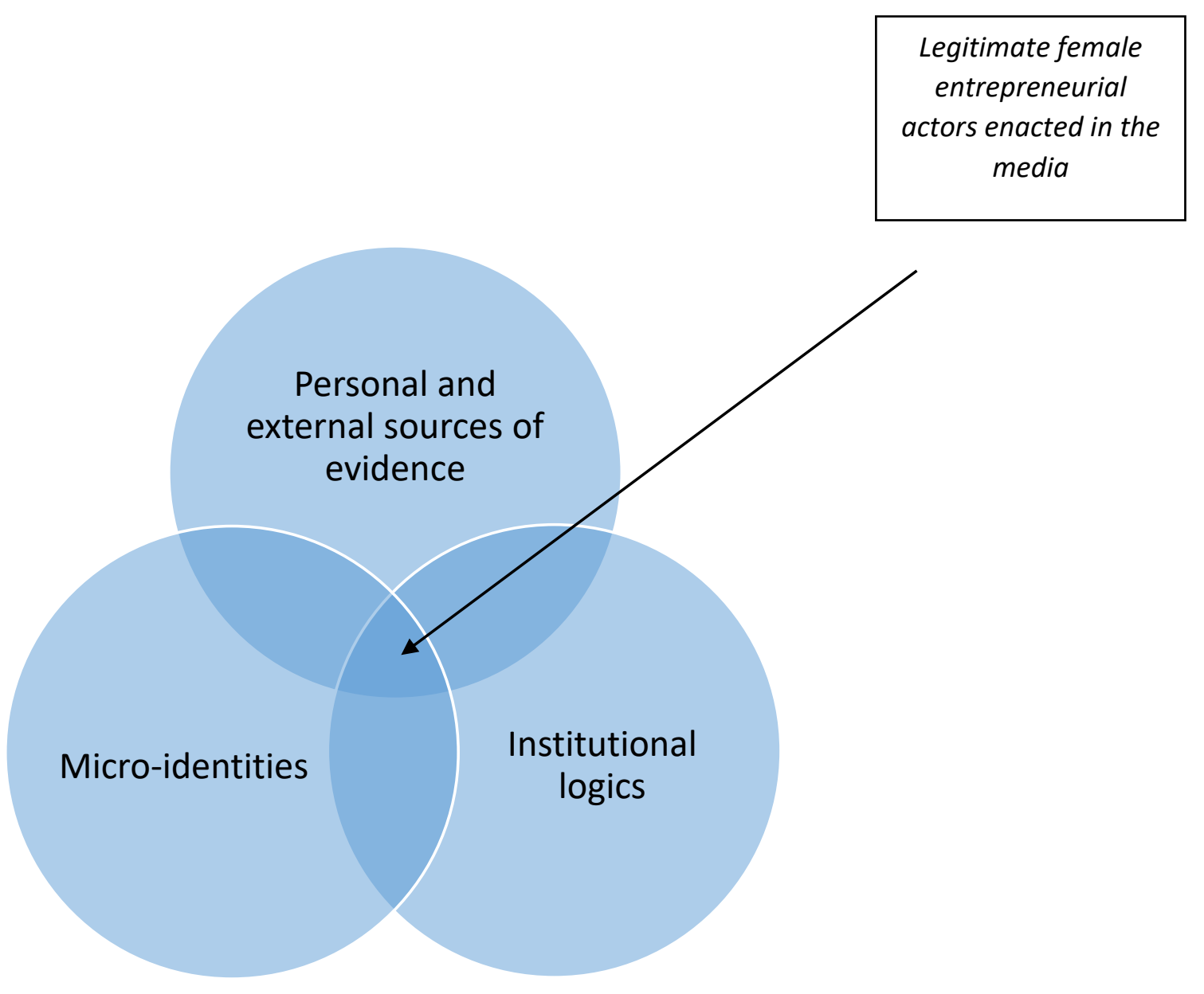

Fig 2: The enactment of legitimate female entrepreneurial identities 


\section{Limitations and future research}

While our study has made a valuable contribution to knowledge of female entrepreneur identity, we acknowledge the limitations of this study and the scope for future investigations to advance identity research. As previously acknowledged, this research article is interpretive in nature which limits its generalisability. We have identified how female entrepreneurs are challenging gendered expectations and disrupting existing institutional logics in the UAE. Future research might adopt institutional theory to explore how identity is being used to legitimate female entrepreneurialism and disrupt institutional logics in other settings. We particularly encourage further investigation of the construction of female entrepreneurial identity in other patriarchal societies to develop a richer understanding of how context influences this process. Additionally, future research might explore whether the identity dimensions identified in this study, similarly apply in contexts where women have greater autonomy. Researchers might also observe a fuller range of the on and offline marketing strategies and practices female entrepreneurs adopt, to negotiate a greater role in the public space, including, blogs, podcasts and public speaking, and the pursuit of accreditations and industry awards. It would be valuable to gain more perspectives of female entrepreneurship by examining attitudes towards its legitimacy from a wider set of stakeholders. We believe that research that takes these ideas forward is important, as the field still lacks a full understanding of when, why, and how female entrepreneurs construct and enact identity to secure legitimacy.

\section{Conclusion}

This study set out to explore how women produce an entrepreneurial identity to secure legitimacy within the highly-gendered culture of the Middle East. Through a netnographic study, we find that these identities are constructed and legitimated through the careful curation and presentation of micro aspects of identity, personal and external sources of evidence, and adherence to the institutional logics of differing institutional settings. Such institutional pluralism enables female entrepreneurs to claim legitimacy by appearing familiar, fitting in within their own institutional setting, and acknowledging the support and endorsement of family and government. Yet, also appearing different, by providing evidence of their engagement with Western ideals to demonstrate that they are also unconstrained by their institutional setting. 
Our study makes three key contributions to enrich the female entrepreneurial literature. Firstly, we highlight how women construct an entrepreneurial identity as a means to secure legitimacy. We identify how women present a coherent entrepreneurial identity which draws on a range of evidence from to claim legitimacy. Such evidence includes both personal and external sources of evidence which borrow from differing institutional settings. By highlighting the role of institutional pluralism, we add to the growing interest in the processes of identity construction.

Secondly, by exploring entrepreneurial identity construction within a stronglygendered institutional setting, we provide a gendered and novel contextual view to add theoretical depth to contemporary conceptualisations of entrepreneurial legitimacy.

Thirdly, we identify how women negotiate a greater role for themselves in the public space. We identify how female entrepreneurialism in the UAE is legitimised by the media, which also helps to secure socio-political legitimation for female entrepreneurial activity within a highly-gendered society; a process which has previously been seen as problematic for women. Therefore, we add to knowledge of how entrepreneurship can give women increased agency and disrupt existing institutional arrangements which might constrain women.

This study has a number of important implications for policy makers and regional development bodies. The UAE has set ambitious targets for entrepreneurship with a stated intention to increase numbers of female entrepreneurs by 2021 . However, women in these societies still face a number of informal constraints on their independent economic activity, making the legitimation of their entrepreneurial activity an important priority. While the UAE Government has established generous funding for female start-ups, it is important that further support is given to increase its social acceptance. This study provides evidence of how female entrepreneurs use the media to create legitimacy for themselves. Policy makers might now consider how the media may be harnessed to increase public awareness of the value and contribution female entrepreneurs are making to society. Although our findings suggest that international business education is valued, domestic business education and entrepreneurial training might be further boosted. Colleges and universities might also offer female entrepreneurs media training to provide women with the skills to undertake media interviews. Additionally, female entrepreneurs may benefit from access to training in other forms of marketing communications such as public relations, social media and public speaking. Such interventions might allow women to take up a greater role in the public space and help shape public perceptions about what is legitimate for women. 
Women have overcome poverty

Women have overcome stigma to build success

Personal

Many of the women entrepreneurs draw strength from crucible experiences

Challenges

The women explain how they overcome cultural restrictions to succeed

Cultural

Pursuits

Personal narratives

Women include anecdotes to showcase how they have travelled regularly in

the west for business

Interviews with the women draw on their personal international travel and experiences

Women have worked for top financial institutions

Personal

Women draw on prior international career experience

Most of the women speak several languages fluently including English for business

Accreditation

Female entrepreneurs are keen to discuss their western education

Women have achieved higher level Masters Degrees

Interviews frequently include women's achievement of an International MBA

Technical ability is revealed through their digital marketing skills

Women have digital analytical skills and competency with different platforms

Women have e-commerce expertise

Women want to be viewed as international entrepreneurs

and inspirational to others

They are willing to be creative and plan for future expansion of their business

Women want to be seen to be able to scale ventures and show resilience to challenges

Women want to be appreciated as hard-working and

equal to others in their business sector

Women operate as entrepreneurs with more than one interest

Respect of others is crucial for female entrepreneurs

Passion for their business was demonstrated

Women display an appetite to succeed and grow their own skills as their business develops

Business and

Technical Acumen

Visionary

accomplishments

\section{Passion}

The conversations with the women show they are able to finance using bootstrapping

Conviction to succeed in their chosen business sector

Table 2: Results of thematic analysis 
Women talk about their success and winning national business awards Many women draw on their international recognition

Women showcase their international celebrity connections during the conversation

International government department support of their business is noted

Women publically discuss their financing

Female entrepreneurs revealed how they

financed their business activity using investors from UAE and Europe

Many women finance using family and friends investment

Women get financing from their husbands

Women want to show they have support from their family

Women were keen to espouse the support received from friends

Conversations revealed how male family members gave their full support to the women

Women want to impact wider society with their business

Women want to break down cultural stereotypes and misconceptions

Offering training to others to encourage development is important for women

All women want to be seen as employers, enhancing the careers of others.

Women want to be seen as changing expectations of women in business

Women reference their encouragement of young aspiring entrepreneurs

Table 3: Results of thematic analysis
National and international External endorsement endorsement

National and internal

finance

External Funding

Support from family and friends

External support

Impact on wider society

External impact

Developing others

Role Models 


\section{References}

Ahl, H and Marlow S (2012) Exploring the dynamics of gender, feminism and entrepreneurship: advancing debate to escape a dead end? Organization 19(5): 543-562.

Aldrich, HE and Fiol, CM (1994) Fools rush in? The institutional context of industry creation. Academy of Management Review 19(4): 645-670.

Alsos GA and Ljunggren E (2017) The role of gender in entrepreneur-investor relationships: A signaling theory approach. Entrepreneurship Theory and Practice 41(4): 567-590.

Anderson AR and Warren L (2011) The entrepreneur as hero and jester: Enacting the entrepreneurial discourse. International Small Business Journal 29(6): 589-609.

Bastian BL, Sidani YM and El Amine Y (2018) Women entrepreneurship in the Middle East and North Africa. Gender in Management: An International Journal 33(1): 14-29

BBC 2019 Saudi Arabia allows women to travel independently. Available at: https://www.bbc.co.uk/news/world-middle-east-49201019. (accessed 12 August 2020).

Converse PE (1987) Changing conceptions of public opinion in the political process. The Public Opinion Quarterly 51:.S12-S24.

De Clercq D and Voronov M (2009) Toward a practice perspective of entrepreneurship: Entrepreneurial legitimacy as habitus. International Small Business Journal 27(4): 395-419.

Deephouse DL (1996) Does isomorphism legitimate? Academy of Management Journal 39(4): 10241039.

Dees JG and Starr JA (1992) Entrepreneurship through an Ethical Lens: Dilemmas and Issues for Research and Practice Issue 81 of Working article series (Sol. C. Snider Entrepreneurial Center). Boston: Wharton School of the University of Pennsylvania, Snider Entrepreneurial Center.

DeRue DS and Ashford SJ (2010) Who will lead and who will follow? A social process of leadership identity construction in organizations. Academy of Management Review 35(4): 627-647.

Down, S (2006) Narratives of enterprise: Crafting entrepreneurial self-identity in a small firm. Edward Elgar Publishing. 
El-Sokari H, Van Horne, C, Huang ZY,Al Awad M (2020) Entrepreneurship: An Emirati perspective Available at: https://www.gemconsortium.org/economy-profiles/uae (accessed 10 March 2020)

Falck, O, Heblich, S and Lüdemann, E (2009) Identity and entrepreneurship. CESifo Working Article, No. 2661, Center for Economic Studies and ifo Institute (CESifo), Munich

Fauchart, E and Gruber, M (2011) Darwinians, communitarians, and missionaries: The role of founder identity in entrepreneurship. Academy of Management Journal 54(5): 935-957.

Fisher, G Kuratko DF Bloodgood JM and Hornsby JS (2017) Legitimate to whom? The challenge of audience diversity and new venture legitimacy. Journal of Business Venturing 32(1): 52-71.

Fletcher-Brown, J, Turnbull, S, Viglia, G, Chen, T and Pereira, V (2020) Vulnerable consumer engagement: how corporate social media can facilitate the replenishment of depleted resources. International Journal of Research in Marketing.

Foss L, Henry C, Ahl H and Mikalsen GH (2019). Women's entrepreneurship policy research: a 30year review of the evidence Small Business Economics 53(2): 409-429.

Garud, R, Gehman, J and Giuliani, AP (2014) Contextualizing entrepreneurial innovation: A narrative perspective. Research Policy 43(7): 1177-1188.

Gioia DA and Chittipeddi K (1991) Sensemaking and sensegiving in strategic change initiation. Strategic Management Journal 12(6): 433-448.

Gioia DA, Corley KG and Hamilton AL (2013b) Seeking qualitative rigor in inductive research: Notes on the Gioia methodology. Organizational Research Methods 16(1): 15-31.

Gioia DA, Patvardhan SD Hamilton AL and Corley KG (2013a) Organizational identity formation and change. Academy of Management Annals 7(1): 123-193.

Glynn MA (2000) When cymbals become symbols: Conflict over organizational identity within a symphony orchestra. Organization Science 11(3): 285-98.

Goby VP and Erogul MS (2011) Female entrepreneurship in the United Arab Emirates: Legislative encouragements and cultural constraints. Women's Studies International Forum 34 (4): 329 334. Pergamon.

Granovetter M (2000) The economic sociology of firms and entrepreneurs. Entrepreneurship: The Social Science View: 204-275.

Greene, FJ, Han, L and Marlow, S (2013) Like mother, like daughter? Analyzing maternal influences upon women's entrepreneurial propensity. Entrepreneurship Theory and Practice 37(4): 687711. 
Greenwood, R, Raynard, M, Kodeih, F, Micelotta, ER and Lounsbury, M (2011) Institutional complexity and organizational responses. Academy of Management Annals 5(1): 317-371.

Guest, G, Bunce, A and Johnson, L (2006) How many interviews are enough? An experiment with data saturation and variability. Field methods 18(1): 59-82.

Hamilton E (2013) The discourse of entrepreneurial masculinities (and femininities).

Entrepreneurship \& Regional Development 25(1-2):.90-99.

Hamilton E (2014) Entrepreneurial narrative identity and gender: A double epistemological shift. Journal of Small Business Management 52(4): 703-712.

Hamman R (2007) Cyborgasms: Ten years on and not enough learned. In Online Matchmaking Palgrave Macmillan: London: 31-39.

Harmon, DJ, Green Jr, SE and Goodnight, GT (2015) A model of rhetorical legitimation: The structure of communication and cognition underlying institutional maintenance and change. Academy of Management Review 40(1): 76-95.

Hattab H (2012) Towards understanding female entrepreneurship in Middle Eastern and North African countries. Education, Business and Society: Contemporary Middle Eastern issues.

Henry C, Foss L and Ahl H (2016) Gender and entrepreneurship approaches: A methodological review. International Small Business Journal (33): 649-666.

Hogg, MA and Terry, DI (2000) Social identity and self-categorization processes in organizational contexts. Academy of Management Review 25(1): 121-140.

Howe-Walsh L, Turnbull S, Khan S and Pereira, V. (2020). Exploring career choices of Emirati women in the technology sector. Journal of Organizational Effectiveness: People and Performance. Epub ahead of print https://doi.org/10.1108/JOEPP-01-2020-0007

Hsu G and Hannan MT (2005) Identities, genres, and organizational forms Organization Science 16(5): 474-490.

Itani H Sidani YM and Baalbaki I (2011) United Arab Emirates female entrepreneurs: motivations and frustrations Equality, Diversity and Inclusion: An International Journal.

Jennings JE and Brush CG (2013) Research on women entrepreneurs: challenges to (and from) the broader entrepreneurship literature? The Academy of Management Annals 7(1): 663-715.

Kirdar S (2010) United Arab Emirates. Women's Rights in the Middle East and North Africa. New York: Freedom House.

Kiss AN, Danis, WM and Cavusgil, ST (2012) International entrepreneurship research in emerging economies: A critical review and research agenda. Journal of Business Venturing 27(2): 266290. 
Kozinets RV (1998) On netnography: Initial reflections on consumer research investigations of cyberculture ACR North American Advances.

Lamin, A and Zaheer, S (2012) Wall Street vs. Main Street: Firm strategies for defending legitimacy and their impact on different stakeholders. Organization Science 23(1): 47-66.

Laverty S M (2003) Hermeneutic phenomenology and phenomenology: A comparison of historical and methodological considerations. International Journal of Qualitative Methods 2(3): 21-35.

Leitch CM and Harrison RT (2016) Identity, identity formation and identity work in entrepreneurship: conceptual developments and empirical applications. Entrepreneurship and Regional Development 28(3-4): 177-190.

Lewis, KV (2015) Enacting entrepreneurship and leadership: A longitudinal exploration of gendered identity work. Journal of Small Business Management 53(3): 662-682.

Lounsbury M and Glynn MA (2001) Cultural entrepreneurship: Stories, legitimacy, and the acquisition of resources. Strategic Management Journal 22(6-7): 545-564.

Marlow, S and McAdam, M (2015) Incubation or induction? Gendered identity work in the context of technology business incubation. Entrepreneurship Theory and Practice 39(4): 791-816.

McCombs, ME and Shaw, DL (1972) The agenda-setting function of mass media. Public Opinion Quarterly 36(2): 176-187.

Middleton, KLW (2013) Becoming entrepreneurial: gaining legitimacy in the nascent phase. International Journal of Entrepreneurial Behavior \& Research 19(4): 404-424

Nagy, BG, Pollack, JM, Rutherford, MW and Lohrke, FT (2012) The influence of entrepreneurs' credentials and impression management behaviors on perceptions of new venture legitimacy. Entrepreneurship Theory and Practice 36(5): 941-965.

Navis C and Glynn MA (2011) Legitimate distinctiveness and the entrepreneurial identity: Influence on investor judgments of new venture plausibility. Academy of Management Review 36(3): 479-499.

Newbery, R., Lean, J., Moizer, J. and Haddoud, M., 2018. Entrepreneurial identity formation during the initial entrepreneurial experience: The influence of simulation feedback and existing identity. Journal of Business Research 85: 51-59.

Orser, B, Riding, A and Li, Y (2019) Technology adoption and gender-inclusive entrepreneurship education and training. International Journal of Gender and Entrepreneurship 11(3): 273-298.

Orser, B, Coleman, S and Li, Y (2020) Progress or pinkwashing: who benefits from digital womenfocused capital funds? Small Business Economics 55(2): 363-387.

Orser, BJ, Elliott, C and Leck, J (2011) Feminist attributes and entrepreneurial identity. Gender in Management: An International Journal 26(8): 561-589. 
Pollock, TG and Rindova, VP (2003) Media legitimation effects in the market for initial public offerings. Academy of Management Journal 46(5): 631-642.

Rao, H. (2008). Market rebels: How activists make or break radical innovations. Princeton University Press.

Rutherford, MW, Buller, PF, and Stebbins, JM (2009). Ethical considerations of the legitimacy lie. Entrepreneurship Theory and Practice 33(4): 949-964.

Seo, MG and Creed, WD (2002) Institutional contradictions, praxis, and institutional change: A dialectical perspective. Academy of Management Review 27(2): 222-247.

Shepherd, D and Haynie, JM (2009) Family business, identity conflict, and an expedited entrepreneurial process: A process of resolving identity conflict. Entrepreneurship Theory and Practice 33(6): 1245-1264.

Shirokova G, Tsukanova T, and Morris MH (2018) The moderating role of national culture in the relationship between university entrepreneurship offerings and student start-up activity: an embeddedness perspective. Journal of Small Business Management 56(1): 103-130.

Stead V (2017). Belonging and women entrepreneurs: Women's navigation of gendered assumptions in entrepreneurial practice. International Small Business Journal 35(1): 61-77.

Stets, JE and Burke PJ (2000) Identity theory and social identity theory. Social Psychology Quarterly: 224-237.

Stinchcombe AL (1965) Social structure and organizations. Handbook of Organizations, Routledge, pp.142-193.

Suchman MC (1995) Managing legitimacy: Strategic and institutional approaches. Academy of Management Review 20(3): 571-610.

Suddaby R and Greenwood R (2005) Rhetorical strategies of legitimacy. Administrative Science Quarterly 50(1): 35-67.

Sveningsson S and Alvesson M (2003) Managing managerial identities: Organizational fragmentation, discourse and identity struggle. Human Relations 56(10): 1163-1193.

Swail J and Marlow S (2018) Embrace the masculine; attenuate the feminine'-gender, identity work and entrepreneurial legitimation in the nascent context. Entrepreneurship and Regional Development 30(1-2): 256-282. 
Thompson-Whiteside, H Turnbull S and Howe-Walsh L (2018) Developing an authentic personal brand using impression management behaviours. Qualitative Market Research: An International Journal 1(1)23: 166-181.

Thompson-Whiteside, H, Turnbull, S and Howe-Walsh, L (2020) Advertising: should creative women be expected to 'fake it?'. Journal of Marketing Management: 1-26.

Thompson-Whiteside, H and Turnbull, S (2020) \#Metoovertising: The institutional work of creative women looking to change the rules of the advertising game. Journal of Marketing Management: $1-24$.

Tlaiss H A (2015) Entrepreneurial motivations of women: Evidence from the United Arab Emirates. International Small Business Journal 33 (5): 562-581.

Tornikoski and Newbert SL (2007) Exploring the determinants of organizational emergence: A legitimacy perspective. Journal of Business Venturing 22(2): 311-335.

Überbacher F (2014) Legitimation of new ventures: A review and research programme. Journal of Management Studies 51(4): 667-698.

Vaara, E and Monin, P (2010) A recursive perspective on discursive legitimation and organizational action in mergers and acquisitions. Organization Science 21(1): 3-22.

Van Horne C, Zengyyu V and Al-Awad MM (2011) GEM report on Entrepreneurship in the United Arab Emirates Available at https://www.zu.ac.ae/main/en/research/publications/ books reports/2011/2011\%20GEM\%20Re port\%20on\%20Entrepreneurshio\%20in\%20the\%20UAE.pdf (accessed 5 March 2020)

van Werven, R, Bouwmeester, O. and Cornelissen, JP (2015) The power of arguments: How entrepreneurs convince stakeholders of the legitimate distinctiveness of their ventures. Journal of Business Venturing 30(4): 616-631.

Vision 2021, 2020 Available at https://www.vision2021.ae/en/uae-vision/list/united-in-knowledge (accessed 10 March 2020)

Welter F (2011) Contextualizing entrepreneurship—conceptual challenges and ways forward. Entrepreneurship Theory and Practice 35(1): 165-184.

Welter F, Baker T, Audretsch, DB and Gartner, WB (2017) Everyday entrepreneurship - a call for entrepreneurship research to embrace entrepreneurial diversity 41(3): 311-321. 
Williams A, Wallis J and Williams P (2013) Emirati women and public sector employment: the implicit patriarchal bargain. International Journal of Public Administration 36(2): 137-149.

Zeidan S and Bahrami S (2011) Women entrepreneurship in GCC: A framework to address challenges and promote participation in a regional context. International Journal of Business and Social Science 2(14): 100-107. 